\title{
HIV and AIDS in rural Tonga culture
}

\begin{tabular}{|c|c|}
\hline $\begin{array}{l}\text { Author: } \\
\text { Vincent Ncub }\end{array}$ & \\
\hline $\begin{array}{l}\text { Affiliation: } \\
{ }^{1} \text { Department } \\
\text { Theology, Fac } \\
\text { Theology, Uni } \\
\text { Pretoria, Sout }\end{array}$ & $\begin{array}{l}\text { f Practical } \\
\text { lty of } \\
\text { ersity of } \\
\text { Africa }\end{array}$ \\
\hline $\begin{array}{l}\text { Project leade } \\
\text { M.J.S. Masane } \\
\text { Project numb }\end{array}$ & $\begin{array}{l}: \\
\text { er: } 02467526 \\
\text { er }\end{array}$ \\
\hline $\begin{array}{l}\text { Description: } \\
\text { This research } \\
\text { project, 'Pastc } \\
\text { Trauma Couns } \\
\text { by Prof. Dr Ma } \\
\text { Department o } \\
\text { Theology, Fac } \\
\text { Theology, Uni } \\
\text { Pretoria. }\end{array}$ & $\begin{array}{l}\text { s part of the } \\
\text { ral Care and } \\
\text { elling', directed } \\
\text { ake Masango, } \\
\text { f Practical } \\
\text { lty of } \\
\text { jersity of }\end{array}$ \\
\hline $\begin{array}{l}\text { Correspondin } \\
\text { Vincent Ncub } \\
\text { masango@up }\end{array}$ & $\begin{array}{l}\text { g author: } \\
\text {, maake. } \\
\text { ac.za }\end{array}$ \\
\hline $\begin{array}{l}\text { Dates: } \\
\text { Received: } 15 \mathrm{~J} \\
\text { Accepted: } 26 \\
\text { Published: } 30\end{array}$ & $\begin{array}{l}\text { an. } 2016 \\
\text { uly } 2016 \\
\text { Nov. } 2016\end{array}$ \\
\hline $\begin{array}{l}\text { How to cite th } \\
\text { Ncube, V., } 201 \\
\text { AIDS in rural T } \\
\text { HTS Teologies } \\
\text { Theological St } \\
\text { a3332. http:// } \\
\text { org/10.4102// }\end{array}$ & $\begin{array}{l}\text { is article: } \\
6, \text { 'HIV and } \\
\text { onga culture', } \\
\text { Studies/ } \\
\text { dies } 72(1) \text {, } \\
\text { dx.doi. } \\
\text { ts.v72i1.3332 }\end{array}$ \\
\hline $\begin{array}{l}\text { Copyright: } \\
\text { (C) 2016. The } \\
\text { Licensee: AOS } \\
\text { is licensed un } \\
\text { Creative Comr } \\
\text { Attribution Lic }\end{array}$ & $\begin{array}{l}\text { uthors. } \\
\text { S. This work } \\
\text { ler the } \\
\text { nons } \\
\text { ense. }\end{array}$ \\
\hline Read online: & \\
\hline 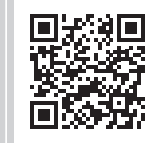 & $\begin{array}{l}\text { Scan this QR } \\
\text { code with your } \\
\text { smart phone or } \\
\text { mobile device } \\
\text { to read online. }\end{array}$ \\
\hline
\end{tabular}

Thirty-five years has gone by since the first diagnosis of HIV in Zimbabwe. Causes and reasons for the disease and its spread vary from place to place and from society to society. In some cases, the usage of needles and other medical apparatus is blamed for causing the disease. In some other instances, some religious beliefs are held responsible for the pandemic. However, it is a different case with the Tonga females of the Pashu community in Zimbabwe. The belief is that HIV among the Tonga females is perpetuated by some cultural practices and beliefs. The practices and beliefs pose a danger to the lives of the Tonga females from the age of infancy to that of elderly women. The culture of silence, loyalty and submissiveness has even aggravated the suffering of these people. The culture has denied them an opportunity to seek medical aid and pastoral therapy. Hope for life and a future for these people are inevitably lost. The study is, therefore, an effort to validate the assumed claim that the Tonga females are exposed to HIV by some of the cultural practices. It is also the purpose of this study to create a pastoral care methodology which will be used to view the problem from a pastoral perspective. A review of the alleged cultural practices is also the business of this study.

\section{Introduction}

Although the prevalence of HIV and AIDS among the Tonga people is relatively low compared to the people in other parts of Zimbabwe, the problem is not about the prevalence per se, but is about how they are infected. The question is basically not about how high the HIV prevalence is, but about the nature of the factors that influence the spread of HIV. The Tonga people constitute about $4 \%$ of the Zimbabwean population (Weinrich 1977:104). This small group of people would be threatened with extinction if the HIV issue is not adequately addressed. Apart from HIV, this group of people is not spared from other social challenges such as the country's weak economy and other life-threatening diseases such as malaria. Of the mentioned challenges, HIV is the most dreaded. To adequately address the HIV issue among the rural Tonga females, the aspect of culture should be dealt with sufficiently.

\section{Historical background of the Tonga females in the context of HIV}

This study was about a small group of people called the Tonga. These people live as a small community under the chief Pashu in the Binga District. Since the first diagnosis of HIV in Zimbabwe, the Tonga females have been more affected by this disease than their male counterparts. This was the reason why the study focused on the females of this community. Cultural roles and beliefs in this patriarchal community have posed a danger to the lives of the females. Females have been vulnerable to these cultural practices which have not respected their place in the community. The way these people are perceived by the community leaves a lot to be desired. They are best described as quiet, loyal, submissive and understanding. Arguably this kind of culture has affected them negatively in this era of HIV. A story involving a young female aged 20 and her uncle aged 40 shows how this culture of silence has adversely affected the people. In the story, the female was sexually abused by her uncle. It was discovered that she was also infected with HIV. This story brought to light what was behind the scenes in the Tonga patriarchal society.

\section{Aim and objectives}

This study was predominantly aimed at unearthing the assumed cultural factors which were believed to have influenced the spread of HIV among the Tonga females. It was still the aim of

Note: This article represents a reworked version of aspects from the PhD dissertation of Vincent Frank Ncube, 'HIV and AIDS in rural Tonga culture', prepared under the supervision of Prof. Dr Maake Masango, Department of Practical Theology, University of Pretoria, South Africa. 
the study to mitigate the situation by creating a pastoral therapeutic intervention for the affected.

The objectives were to assess the claim that the Tonga females were the victims of circumstances in the context of HIV. The study was also undertaken to assess the consequences suffered by the concerned females. Lastly the study was meant to create a relevant model of pastoral care for these females.

\section{Method used for conducting the study}

In this study, the most appropriate approach was the qualitative method. In contrast to the quantitative approach, qualitative research is an inquiry process of understanding where a researcher develops a holistic picture, analyses words, reports, detailed views of the informants, and conducts the study in a natural setting (Maree 2013:259).

On the other hand, in the qualitative study, the hypothesis is not the emphasis. In the qualitative study, facts cannot be isolated from the domain of values or moved from the ideological inscription. Events are understood within the socioeconomic and political contexts with an emphasis on ideological critique and praxis. Henning buttresses this point when she says that in qualitative research, knowledge is constructed in the act of critique in a dialectical process of deconstructing and reconstructing the world (2013:23). Dealing with HIV and the Tonga females is dealing with a worldview of a particular people. Also dealing with a human being is to deal with an all-rounder. This means that the Tonga females as subjects are political, religious and social beings. To understand the social life experience of individuals or community, interaction as a method was necessary. In this study, it was considered that the most appropriate method for gathering information about the Tonga people was conducting interviews. But before the information gathering, the cognition of ethical principles was employed.

\section{Ethical considerations as employed in this study}

Taking into account the nature of the study, ethical considerations were important to note. The study dealt with the females and HIV. This was a sensitive undertaking which called for treading with caution. Although it might have been difficult to predict the nature of the consequences in the social science area, it remained intrinsically good to consider ethical principles for the envisaged problems (Oliver 2011:31). During the interviews, the theories of 'intrinsically and instrumentally good' were observed. This theory maintains that what is done in a study has to benefit both the one conducting the study and the participants as well. In this regard, the Tonga females were not the objects in the study. They were people who had the right to benefit from the study. To help the affected individuals, groups or families to live positively with their situation, a pastoral care methodology was important. Taylor's motif of the Shepherd was a theory meant to help the affected individuals or groups to have a new thinking about themselves in the context of pastoral care (Taylor 1994:34-80). This redefined the lives of the females in question. It also demystified a misconception commonly held in the Pashu community by males that females were lesser equals.

\section{Methods for data gathering Interview}

An interview is a study method which is basically used to gather information about the subject or object of the study. It involves a direct personal contact with the participant who is asked to answer questions relating to the problem dealt in the research (Bless 2013:193). There are three forms of interviews: structured interviews, semi-structured interviews and unstructured interviews. The preferred method used in the study was the unstructured interview. In this study, the issue of the relationship between the interviewer and the interviewees was of great importance. The complexity of accessing information from a community of people who were believed to be so secretive would not be fully understood. One would envisage predicaments of acceptability and cocooperativeness. This meant that conducting interviews among the Tonga females would not be taken for granted. Failure to address the anticipated challenges would render void the attempt to venture into the whole interview exercise.

In view of this, the study subsequently considered one-to-one or open-ended interviews as a method of data collection. Unlike structured interviews, this method gives much room for the participant to freely contribute to the study. Advantages of unstructured interviews are that concepts and problems are clarified. These interviews allow also for the discovery of new aspects of the problem by exploring in detail the explanations supplied by the respondents (Bless 2013:197).

In this study, this method allowed interaction and mutual relationship between the one conducting the interviews and the participants. This assisted in creating a good and conducive ground for working relations. This meant that the researcher had to suspend preconceived ideas or knowledge about these people. More often than not, people who have heard about the Tonga people have failed to accept them as human beings. There are a lot of misconceptions about these people. These misconceptions include their education, dressing, accommodation, religion and way of life in general. These misconceptions have become a stigma which has made some of these people believe that this is what they are. It was therefore imperative for one to demystify these misconceptions before contemplating engaging with them. The one-to-one kind of interviews would yield the desired results if properly managed.

\section{Conducted interviews}

There were five females randomly sampled from the concerned community for this study. All of these people were aged above 34 . The reason for selecting females only was to 
try and maximise the female voice in this study. The aim of the study was to hear the females speak out. Of these participants, two were nurses and one of these nurses was a midwife. Questions asked during the interview were meant to probe more dialogue between the interviewer and the interviewees (Grix 2010:128). Of interest was that the questions asked showed a common trend of response. Almost all the interviewees cited cultural beliefs, ancestral veneration and witchcraft as the major factors influencing the high prevalence of HIV among the Tonga people.

\section{Interview 1}

The researcher decided to indicate the specific interviewee by means of numbers, instead of names, for confidentiality purposes. The primary probing question was, 'Is it true that most Tonga females are more vulnerable to HIV than their male counter parts?' The second one was, 'is it true that those who test HIV positive believe that they are bewitched?' From these main questions, responses led to many other questions. The study findings were that people in Pashu do not volunteer to go for HIV testing because of the fear of being found positive. Others were shy to go for testing. The first respondent cited also the witchcraft factor. The belief was that what one was suffering from had nothing to do with medical examination, and that traditional consultation was enough since any kind of illness was ascribed to human cause.

The second interviewee repeated the aspect of witchcraft mentioned by the first one and the conclusion was that a patient felt she was already dying so why should she go for testing. This interview also showed that some of these females felt that they suffered from allergies and not HIV. For these people going for HIV testing was a waste of time. There was also the issue of stigmatisation. An example of this stigmatisation included that of peers, stigmatisation within the family, at work place, in schools and colleges and in the community at large. In Tonga culture, issues of sex and sexuality are held in high esteem. HIV would be labelled as a result of promiscuity. People who are HIV positive would not freely mingle or interact with counterparts who are not HIV positive because they would be seen as loose people.

In the third interview, a new dimension of HIV perspective was introduced. The reason why most of the Tonga females do not go for HIV testing was found to be ignorance. The people of this community lacked knowledge of the infection. They also tend to believe that this disease was a death sentence from God. This meant that a person suffering from AIDS was punished by God.

In the fourth interview, the interviewee, a lady, stated that their reluctance to go for testing was based on the distance of the clinics and hospitals from their homes. It was difficult for them to get there. This respondent also mentioned cultural and religious beliefs as factors influencing them not to be tested.
During the fifth interview, it was discovered that most people in the area under study do not value testing because the Zimbabwean law does not force people to do so. Those who go for testing do so voluntarily. This has encouraged most people to be reluctant. In view of the above findings, the researcher concluded that the issue of HIV among the Tonga females was a pastoral issue. It was pastoral in the sense that there was pain. These females were afflicted. They had also lost hope of living. What they saw was the dark side of life. The whole issue called for pastoral care.

\section{Theoretical viewpoints of pastoral in the context of HIV and AIDS among Tonga females}

Harold Taylor (1994) has coined a pastoral care methodology in which the motif of a 'shepherd' was his entry point. He has exhaustively expressed the shepherd metaphor in his book called, Tend my sheep. The shepherd is a well-known figure among many agricultural people, and in ancient Israel everyone understood what the work of a shepherd was. Flocks of sheep and goats were important possessions, just as they are today in many countries (Taylor 1994:7). This idea of a caring shepherd was very familiar and meaningful to the people of Israel and many preachers and writers used it. In this pastoral care methodology, Jesus is the shepherd. He is the real model of a shepherd. Other figures referred to as shepherds by Taylor include disciples, ordained ministers and lay church workers. In the context of the study, the shepherds are the ordained ministers of religion, the church workers and traditional leaders such as village heads, chiefs and the community at large. The responsibility of these professionals was to tend the sheep. In this study, ordained ministers had the responsibility of offering pastoral care and counselling to people living with HIV. They were also expected to teach the community about this disease. Chiefs and village heads are expected to scrutinise the community's cultural norms and values. Practices and beliefs such as polygamy and witchcraft which may pose danger to Tonga females should be discouraged by these traditional leaders. Through its structures, the community should offer relevant support to people living with HIV. In other ways, the community as a whole was responsible for caring for the needy in the context of HIV.

\section{Jesus as a model in the context of the study}

Pastoral theology has been built on the theme of shepherd. This was simply because God himself has been viewed supremely as a shepherd. God has been seen as the guider, protector and the liberator (Brister 1977:19-20). In the New Testament Jesus called himself 'the good shepherd' who knew his sheep by name. Of all the self-descriptions he used such as - light, bread, door, way and truth - the motif of shepherd was evidently most prominent in Jesus' thinking. When he saw the crowds, he had compassion for 
them because they were harassed and helpless, like sheep without a shepherd. He conceived his mission 'to the lost sheep of the house of Israel' as costing him his very life's blood. One sheep that has gone astray required more time, skill and devotion than 99 safe on the hillside (Brister 1977:19-20).

In the paragraph above Brister used key terms to portray the shepherding motif of Jesus. These expressions were indicative of the qualities and characteristics, as well as the expectations of a good shepherd. Jesus' model of a shepherd should be viewed as a good example to be emulated by today's shepherd. Brister described Jesus as a shepherd who knew his sheep by their names. This showed the relationship between the shepherd and the sheep. An effective pastoral care is built on a well-established relationship between the counsellor and the counselled. A minister working among the Tonga people should develop good relationships with them in order to help them.

The second key statement used by Brister (1977:20) to describe Jesus' ministry was, 'costing him his very life's blood'. What Brister is saying affirms Taylor's motif of a shepherd. The term 'cost' in this context may refer to commitment associated with looking after the flock. Working with people who are HIV positive might not be that easy. These people may fail to co operate. This could be due to the fear of stigmatisation by the community. In a case where the community develops a negative attitude towards HIVinfected people, it would be difficult to talk of pastoral counselling. In the case of the Tonga females, it could be due to their nature of shyness. They may find it difficult to let other people know that they undergo treatment for HIV. They may also not voluntarily come out in the open for counselling.

In view of these cited challenges, pastoral care may not be easy to administer. But from Brister's expression, the focal point was not the sheep but the shepherd. Grobler (2013:12), in his book titled Person Centred Facilitation, has a different view altogether. His point was that the care giver only facilitates. In other words, he was saying that the one with a problem was the one to shout out for help like Bartimaeus when Jesus was passing by. In this case, both views were crucial. Grobler's view refers to Pastoral counselling where the initiative comes from the individual with a problem. Taylor's view refers to pastoral care where the care giver, knowing the situation, takes the initiative to help the person with a problem. The issue concerning the Tonga females fits well in these two paradigms. These people were in a quandary. The situation was that those who were courageous enough to seek either medical or pastoral help could do so at their own initiative. On the other hand, those who are not able to approach service providers can still find some assistance. It is the shepherd who should be concerned with his sheep and not the other way round. The shepherding motif remained central in pastoral theology.

\section{Individuals, groups, families and communities as the flock which require shepherding}

This part of the study was dealing with Grobler's personcentred therapy which is enshrined in Carl Rogers' 19 propositions. Rogers' 19 propositions explain and describe the pattern of human behaviour at any given time. This theory was then used by Grobler as an approach to pastoral care and counselling. The researcher also used this theory to explain the behaviour of individuals, families and the community under study.

Different individuals or groups of people have different experiences and needs. Grobler (2013:9) has articulated this in Rogers's 19 propositions. Proposition number (1) states that the experiential world of every person is central and personal. This personal world is constantly changing. Following what Grobler said when he used Rogers's proposition (1), it might be appreciated that people's life experiences are different. In view of this, a good care giver working with the Tonga females with HIV would take serious note of the four categories of prospective clients which are individuals, groups, families and communities (Grobler 2013:9). What this implied was that even in the context of HIV epidemic, each case was unique and required special attention.

\section{Pollard's theory of deconstruction as an essentiality in transforming the Tonga mindset}

It may be possible that the gross suffering of these rural Tonga females stems from the society which had failed to hear the voice of women. The Tonga worldview seemed not to emphasise gender sensitivity. In view of this, Pollard's theory of positive deconstruction offers room for transformation. The theory maintains that there is a need to identify the worldview, analyse it, affirm the truth and discover the errors. In short, this theory suggests that each world view may have both truths and errors (Pollard 1998:55-56). This theory addresses issues of attitude. It was therefore up to the affected clients to see what they would do with their situation.

\section{Cultural beliefs as used in this study Definition}

The following perspectives were sufficient to give a clear picture of what culture is. Bourdillon (1997:7) gives a descriptive definition of culture. For him culture included everything that is learned in a society: the language spoken, the behaviour, music and dancing, knowledge and ways of thinking, values, beliefs, technology used at work and leisure - everything. This culture is thought of as something which each generation receives from the elders and passes on to its children (Bourdillon 1997:7). 


\section{Nyokabi Kaman's definition}

Culture can be defined as a people's way of life, including arts, beliefs and institutions passed on from one generation to another Haddad (2011:257).

\section{Musimbi Kanyoro's definition of culture}

Culture is defined by Musimbi Kanyoro as a distinctive way of life, such as love, eating, dancing and worshipping. Culture can be a double-edged sword; it can form a community identity and it can also be used to set apart or to oppress those whom it defines as 'other' (Dube 2003:89).

\section{A sociological definition of culture by Marx}

The Marxist theory holds that culture is a product of the ruling class which serves to maintain domination over the powerless. The Marxist perspective regards culture, therefore, as an ideology that is formulated by those in power for their own ends. It does not serve the interest of all members of the society. According to the Marxist perspective, culture is therefore both materially informed and informing (Dube 2003:89).

It could be appreciated that the variety of definitions provided above was sufficient enough to conceptualise culture. These imply the following: Culture is not natural, but a product of a particular people. Culture is also not static but keeps on changing. This means that culture may not be viewed as universal and static. In view of this, the Tonga culture was therefore unique to them alone. Their way of life was also found to unique to them alone. This argument was enhanced by Haralambos' perspective of culture. He argues that culture is the whole way of life in a particular society. This culture is learned and shared by members of the same society (Haralambos 2008:663). People, patriarchs perhaps, are responsible for the marginalisation of females, because of the power they hold in culture and community.

\section{The Tonga culture as it relates to this study}

Weinrich (1977:13-77) described the Tonga culture as the way of life'. As stated in the paragraphs above, the Tonga culture is best defined in the context of their wholesome life. Their way of life was characterised by groupings under the traditional leaders such as chiefs. The community understudy is under the chieftainship of Pashu. This community is one among other chiefs such as Dobola, Saba, Binga and Siyabuwa, to name but a few. Though, under different chiefs and communities, the Tonga people share one culture. They are neatly knit together as one (Weinrich 1977:13). In a Tonga worldview, it is common practice to inherit the property of a deceased person. This paragraph explains the type of Tonga society which is matrilineal.

\section{Chieftainship}

Although the Tonga people have a matrilineal type of society, the rule is still patriarchal. In the original set-up of the Tonga political affairs, the chief's children cannot takeover the rulership after the death of their father. It is actually the son of the chief's daughter or sister who qualifies to inherit the throne. This person may not only inherit chieftainship, he may also inherit the chief's wives (ibid 1997:13).

In this age of HIV, it was this culture of inheriting spouses of the deceased person which was being scrutinised. The problem of this culture was that it did not consider females as human beings with a right to choose. An inherited female is no different from property she is inherited together with. This dismisses the concept of liberty and freedom. The Tonga females were therefore not at liberty and free to choose the men they want to marry after the death of their husbands. In the context of HIV, this has a negative bearing. If the chief died of AIDS, then all the surviving spouses would be affected and infected. The one who married the chief's wives also became infected. It could also be the other way round. If the one who inherited the chief's wives was HIV positive, then all the chief's wives would be infected. The culture of inheritance was therefore one of the factors influencing the spread of HIV among the Tonga females.

\section{The culture of silence among the Tonga females}

It is also Tonga culture for females to be very loyal to their male counterparts, especially in the case of the married ones. It has already been mentioned previously that the Tonga females are described as quiet, loyal, obedient, submissive and content. True or false, this culture has enslaved these females in this age of the HIV pandemic. This has also exposed them to sexual abuse by males. The culture which was supposed to give protection to its people seems to have turned against them (Tremmel 1997:5-7).

The culture of inheritance introduces yet another Tonga culture of polygamy. Tremmel, an anthropologist working with the Tonga people of the valley, as they were at times commonly called, has given a history of these people in his book, The people of the Great River (1997:5-11). Polygamy among the Tonga people is common. It is not only the chiefs and other influential figures in the society who practised this culture. The study findings were that, even in this century, most of the Tonga people, young and old, still practise polygamy. This problem of polygamy together with inheritance has fuelled the spread of HIV in chief Pasha's community.

Inheritance means marrying someone's wife or husband. This is usually when a man or woman has died. Secondly, it may not be automatically practical. In the case of an old man dying and leaving wives who are also old, today's young men may not have an interest in getting married to such old females. On the other hand, polygamy is questioned in today's situation where unfaithful relationships have ended up in problems of being infected with HIV. Here the question of faithfulness factors in. One unfaithful member of the family may infect the husband who in turn may infect other women of the same family. 


\section{The characteristics of the Tonga females as a factor which has endangered their life in this era of HIV and AIDS}

It has already been alluded to that the Tonga females are negatively described by the community. This description became an advantage to the perpetrators of abuse. Male counterparts took advantage of the female's culture of silence. In terms of conjugal rights, only male counterparts benefited. In a Tonga society, females believed that males were privileged to consent in sexual matters. Females have no right to question their husbands on sexual issues. This was a problem in terms of the HIV pandemic. Males often took advantage of this and infected their spouses. A married woman is not able to say no to her husband who is HIV positive when he makes sexual advances. In like manner, abused married women found it difficult to go back to their parents and relate their situations. If they did, they were advised by their own parents to go back to their husbands. Loyalty has exposed these Tonga females to the danger of being infected with HIV. This disease has easily spread among the Tonga people simply because of some of these practices (interview, 10 July 2015). Apart from the mentioned factors which have influenced the spread of HIV among the Tonga people, beliefs such as ancestors were also questionable.

\section{The Tonga perspective of the concept of ancestors in the context of this study definition of ancestors}

The term ancestor may be defined differently by different people. A good example is Mbiti's definition of the dead. Mbiti (2002:162) calls the departed people the 'living dead'. The understanding is that as soon as a person died, he became a spirit; he was no longer in his mortal body. For Mbiti, the person was still living in the minds of the survived family members. The person became an ancestor and was capable of solving the problems of kin members in times of crisis. The ancestor was also capable of reprimanding and punishing the kin when they failed to recognise the instruction. In Tonga, these ancestors are called Baleza or Mizimu. These are spirits of people who have died long ago. They are associated with names and totems. They pose as consultants of the family members. They may harm a family member or praise him or her (Mugambi 1976:93-94).

The purpose of the above definition and description of ancestors was to show how the Tonga people valued some of the elements of their traditional religion. Their lives as Africans were enshrined in these African traditional religious values. The meaning of their lives has reference to these traditional beliefs. In other words, the Tonga worldview is perceived from a traditional context. Their lives have meaning in the cultural and traditional facets. The aim of this background was to help understand the behaviour of these Tonga females in the context of HIV. It was also to help understand the way these people perceived sickness, suffering and even death. It was also to answer 'why it was at times difficult for them to consider modern medicine over traditional medicines when afflicted with HIV?'

\section{Illness in the context of HIV as seen in this study}

From a western perspective, illness or sickness may be said to be caused by different viruses. A virus is a living thing, too small to be seen without a microscope. It causes an infectious disease in people, animals and plants (Oxford Advanced Learner's Dictionary 2010:1660). This definition means that sickness is natural and may not be caused by human beings intentionally. There are of course diseases such as cholera which is caused by contact with contaminated water. This disease may cause diarrhoea. This does not start with man, but man only becomes a victim. Western perspective of HIV is therefore scientific and requires western medicine.

On the other hand, an African perspective of illness is different from that of a western perspective. Africans have a way of understanding and interpreting sickness. For the Tonga people every sickness has a human agent as a causal explanation. In this case HIV / AIDS were not scientifically caused. The belief was at least someone, a member of immediate family or a relative was responsible for the illness (Bourdillon 1997:71). In this study this explained why most of the Tonga people failed to see AIDS as a natural disease caused by a virus. It also explained why they did not opt to seek medical aid. A common belief was that a person was sick because his ancestors were angry. Another perspective was that an African was not just sick from nowhere but was bewitched. Witchcraft is therefore another antisocial activity in an African worldview which was believed to have influenced the spread of HIV among the Tonga females (ibid 1997:71-72).

\section{Witchcraft is believed to be responsible for influencing the spread of the HIV pandemic definition of witchcraft}

Mbiti (2002:202) says that 'witchcraft' is a term used more popularly and broadly to describe all sorts of evil employment of mystical power, generally in a secret fashion. African societies do not often draw the rather academic distinction between witchcraft, sorcery, evil magic, evil eye and other ways of employing mystical power to do harm to someone or his belongings. Generally the same word is used for all the English terms, and the same person is accused or suspected of employing one or more of these ways of hurting members of his community (Mbiti 2002:202).

This definition was sufficient enough to explain the concept of witchcraft from an African perspective. This antisocial phenomenon was always the answer to any misfortune which may befall an individual or family. This evil force was also blamed for natural disasters such as poor crops 
and drought. It is also believed to be responsible for sickness and death. Arguably, this phenomenon is not an ancient philosophy. It is common even in today's life. The importance of this paragraph is to show how the Tonga females fail to access modern medicine when they test HIV positive. In view of this, no African falls sick without someone being labelled a witch. Even where one is suffering from HIV, the conclusion is that the person is bewitched. It is a conflict of two worldviews: the African and the western philosophies. The western philosophy subscribes sickness and death to a scientific cause while African philosophy points to human beings as the cause of any kind of sickness and death.

In view of the above, culture and its aspects such as ancestors, witchcraft and other religious beliefs were held responsible for influencing the spread of HIV among Tonga females. Because all illness was attributed to some evil spirits or power which was believed to be caused by a member of the family, no western medicine could be of any help. Although it could be over-emphasising to claim that all Tonga people did not go for HIV testing, the focal point was the belief in witchcraft and other evil spells as the cause of the disease. Problems associated with this ideology were that many people would be reluctant and not value visiting medical clinics and hospitals for HIV testing. Secondly, even those who got tested by any means would not believe that it was true that they were suffering from AIDS. A number of these people suffered from the disease and eventually died of it. Some conducted interviews testified to this experience.

\section{Data analysis}

From the study findings it could be appreciated that the Tonga females' vulnerability to HIV and AIDS stems from some cultural practices and traditional beliefs such as witchcraft and ancestors. It could also be appreciated that there were a few who got tested but keep silence because of envisaged family or community negative reactions towards them. What this meant was a confirmation that these females' exposure to the HIV pandemic stems from cultural practices and beliefs. So far, the plight of these people was not adequately addressed but only verified. This suggested a further investigation into how best the situation could be mitigated.

\section{Conclusion and recommendations}

The paper examined the claim that the Tonga females were exposed to HIV infection because of some cultural practices and beliefs which were oppressive. The study findings pointed to these traditional beliefs as the main cause for the suffering of these females in the context of HIV. Although Pastoral care was seen as a possible means to mitigate the situation prevailing on the ground, further investigation into how these cultural practices should be addressed. More interviews should be conducted to possibly further confirm the findings of the study, testing views of those who have more western views due to taking up employment outside the community. The investigation should also consider possible approaches to changing the negative elements of culture as they impact on the transfer of the HIV. Educative programmes which may help the Tonga people to learn and know more about HIV are also important for further investigation.

\section{Acknowledgements Competing interests}

The author declares that he has no financial or personal relationships which may have inappropriately influenced him in writing this article.

\section{References}

Bless, C., 2013, Fundamentals of social research methods. An African perspective, Juta R Company Ltd, Cape Town.

Bourdillon, M.F.C., 1997, Where are the ancestors; changing culture in Zimbabwe, University of Zimbabwe Publication, Harare.

Brister, C.W., 1977, Pastoral care, Harper \& Row Publishers, New York.

Dube, M., 2003, HIV and AIDS and the curriculum, WCC Publication, Geneva.

Grix, J., 2010, The foundation of research, Palgrave Macmillan, New York.

Grobler, H., 2013, Person centred facilitation process, theory and practice, Oxford University Press, Cape Town.

Haddad, B. (ed.), 2011, Religion and HIV and AIDS charting the terrain, University of kwaZulu Natal Press, Pietermaritzburg.

Haralambos, M. \& Holborn, M., 2008, Sociology, themes and perspectives, 7th edn., Harper Collins, London.

Henning, E., 2013, Finding your way in qualitative research, Van Schaick Publishers, Pretoria.

Maree, K., 2013, First step in research, Van Schaik Publishers, Pretoria.

Mbiti, J.S., 2002, African religions and philosophy, East African Educational Publishers, Nairobi.

Mugambi, J.N.K., 1976, Applied ethics in religion and culture, Acton Publishers, Nairobi.

Oliver, P., 2011, The student's guide to research ethics, Fortress Press, Minneapolis, MN. Oxford Advanced Learner's Dictionary, 2010, 8th edn., Oxford University Press, Oxford.

Pollard, N., 1998, Evangelism made slightly less difficult, Inter- Varsity Press, London. Taylor, H., 1994, Tend my sheep, University Press, Cambridge.

Tremmel, F.M., 1997, The people of the Great River, Mambo Press, Gweru.

Weinrich, A.K.H., 1977, The Tonga people on the Southern shore of Lake Kariba, Mambo Press, Gweru. 